\title{
IMPLEMENTASI HUKUM ISLAM DI KESULTANAN BIMA
}

\section{Muhammad Mutawal}

Dosen Tetap Fakultas IImu Tarbiyah dan Keguruan UIN Mataram, Ketua STIS Al-Ittihad Bima, Mahasiswa Pascasarjana (S3) UIN Jakarta.

\begin{abstract}
Abstrak
Wajah hukum di daerah (Kesultanan) Bima dibentuk oleh dua komponen, yaitu adat Mbojo dan hukum Islam. Transformasi dan perpaduan aturan hukum yang terjadi tidak membawa ketegangan-ketegangan, hukum Adat Mbojo sebagai tuan rumah dan hukum Islam sebagai ajaran agama yang datang kemudian saling melengkapi, menjadi satu-kesatuan dalam menjamin tegaknya hukum di Bima. Tulisan ini menguraikan sisi penerapan hukum Islam di Bima, khususnya berkaitan dengan hukum kelurga, pernikahan, perceraian, dan kewarisan. Temuan ini mengemukakan, bahwa pelaksanaan hukum Islam dalam Badan Hukum Syara' Bima berlaku efektif, hal ini terbukti dalam kasus-kasus, seperti kasus dalam pelanggaran taklik talak yang terjadi antara Im dan suaminya Smdn yang diputus talak satu oleh Badan Hukum Syara' dikarenakan Smdn sebagai suami telah melanggar ikrar taklik talak yaitu meninggalkan isteri selama 7 (tujuh) bulan tanpa nafkah lahir dan batin, demikian juga dalam kasus kewarisan, hukum Islam merupakan dasar dan sumber hukum dari penyelesaian kasuskasus tersebut. Bentuk perpaduan antara adat dengan Islam di Kesultanan Bima, yaitu kecenderungan mengambil alih ketentuan-ketentuan hukum Islam dan menyebutnya sebagai adat.
\end{abstract}

Kata kunci: Adat Mbojo, Kesultanan Bima, Badan Hukum Syara', pernikahan, perceraian, kewarisan.

\begin{abstract}
The law of Bima Sultanate was shaped by two legal traditions, Mbojo custom and Islamic law. The encounter between them did not stir up conflicts and tensions. Mbojo custom representing the local tradition and Islamic law as the external element were complementary each other; they were mutually enforcing. This article examines the implementation of Islamic family law, marriage, divorce and inheritance in Bima Sultanate. This article shows that Islamic family law was applied effectively in Bima. This can be seen from the various legal cases. One example dealt with violation of conditional divorce by Im"s husband, Smdn. The Sultanate Court ruled one repudition on this case because Smdn was proved guilty for breaking his conditional divorce oath by leaving his wife for seven years without any support. The other case was concerned with inheritance where Islamic inheritance law was fully applied. The assimilation of adat and Islam in the Sultanate was realized by applying Islamic law or adopting its stipulations and expressing this in the language of local custom.
\end{abstract}

Keywords: Mbojo custom, Bima Sultanate, Islamic court, marriage, divorce, inheritance 


\section{Pendahuluan: Sejarah Kesultanan Bima}

Dalam sejarah perdagangan Nusantara. Bima tercatat sebagai pelabuhan persinggahan penting. Sejumlah kapal dagang yang berlayar dari Malaka menuju Maluku pada abad ke-15, memilih Bima sebagai tempat transit dan persinggahannya. Kain tenun, kayu cendana, bahan lilin, dan berbagai hasil hutan mudah di dapat lewat pelabuhan ini. Lokasinya di tepi teluk yang dikelilingi pegunungan nan elok di bagian timur Pulau Sumbawa. Dari arah Laut Flores, di sebelah utara, Teluk Bima tampak seperti gerbang. Di balik gerbang itu tidak hanya terdapat pelabuhan besar, melainkan juga ibukota kerajaan yang cukup terpandang di Nusa Tenggara, itulah Kesultanan Bima. Wilayahnya meliputi paruh timur Sumbawa dan daerah Manggarai di bagian barat Flores.

Dalam arsip Majelis Adat Dana Mbojo Bima, kerajaan ini didirikan pada abad ke-14, hasil kesepakatan raja-raja kecil (ncuhi) sewilayah Bima. Dengan modal dasar adat yang mengandung falfasah hidup dan kehidupan itulah, putera sang Bima yang bernama Indera Zamrut berhasil meletakkan dasar yang kokoh bagi pertumbuhan dan perkembangan Kerajaan Bima. Raja dan rakyat selalu menjunjung tinggi asas musyawarah dan samangat Karawi Kaboju (gotong royong) dalam hidup dan kehidupannya.

Pada awal abad ke-17 keharuman nama Kerajaan Bima, mulai berkurang. Peristiwa itu terjadi karena ulah seorang tokoh yang bernama Salisi yang berani menghianati sejarah. la berani melanggar adat yang sudah diadatkan melalui sumpah leluhurnya demi ambisi pribadinya dan ia tidak segan-segan membunuh tokoh-tokoh kerajaan yang dianggap sebagai penghalang. Satu tokoh muda yang luput dari teror Salisi adalah La Ka'i. Setelah melalui perjuangan pahit dengan mengorbankan segalagalanya, La Ka'i bersama La Mbila dengan dukungan rakyat dan bantuan Makassar berhasil mengalahkan Salisi. ${ }^{1}$

Bersamaan dengan itu pula, tepatnya pada tanggal 10 Rabi'ul awal $1018 \mathrm{H}$. (1609 M.), empat orang bangsawan sepakat untuk menerima ajaran Islam yang dibawa oleh pedagang dari Gowa yang lebih dahulu masuk Islam. Keempat orang bangsawan tersebut resmi memeluk agama Islam dan merubah nama mereka menjadi:

- La Ka'i menjadi Abdul Kahir

- La Mbila menjadi Jalaluddin

- Bumi Jara Mbojo menjadi Awaluddin

- Manuru Bata menjadi Syirajuddin. ${ }^{1}$

\footnotetext{
${ }^{1}$ Abdullah Ahmad, Kerajaan Bima dan Keberadaanya, (Bima: Stensilan, 1992), 53.
} 
Pada tahun 1633 M, La Ka'i dinobatkan menjadi Sultan Bima I dengan nama Sultan Abdul Kahir. Pada tanggal 6 Juli 1640, telah menjadi peristiwa penting yang merupakan momentum bagi perkembangan politik, agama dan sosial budaya di kalangan masyarakat Mbojo (Bima) pada masa selanjutnya. Mulai saat itu sistem kerajaan berakhir, diganti dengan sistem pemerintah baru yang bernama kesultanan, yaitu sistem pemerintahan yang berdasarkan Islam dan sistem budaya (adat) yang berpedoman pada norma agama Islam („urf shahih). Mulai saat itu Islam resmi menjadi agama negara, menggantikan posisi agama budaya ( $m a$ kakamba ma kakimbi) yang sudah berbaur dengan Hindu dan Budha. Seiring dengan perubahan agama masyarakat, berubah pula sistem budayanya (adat). Sistem budaya lama yang tidak Islami (,urffasid) diganti dengan adat yang Islami (,urf shahih). Perubahan adat sebagai wujud kebudayaan yang abstrak sangat mempengaruhi wujud kebudayaan konkret, yaitu sistem sosial dan budaya fisik (material). Mulai saat itu perkembangan sistem sosial dan kebudayaan fisik harus berpedoman pada norma agama Islam, dengan perkataan lain kebudayaan Mbojo Islam terutama dari segi substansinya. ${ }^{2}$

Islam dapat diterima dengan baik dan mudah oleh masyarakat Bima yang sebelumnya menganut tradisi lama disebabkan karena antara ajaran Islam dengan adat budaya lama tersebut tidak memiliki perbedaan yang sangat mendasar. Artinya, adat-budaya lama memiliki makna substansi yang hampir mirip dengan ajaran Islam sehingga Islam yang baru datang dapat diterima oleh adat-budaya lama masyarakat Bima walau masih ada sebagian adat-budaya lama tersebut bertentangan dengan ajaran Islam. Ketika Islam sudah menjadi anutan masyarakat Bima, adat yang bertentangan dengan Islam ditinggalkan sehingga tidak ada pertentangan antara adat dan ajaran Islam sebagai ajaran yang baru dianut oleh masyarakat Bima. ${ }^{3}$

Agar adat Mbojo benar-benar menjadi adat yang baik, maka penguasa dalam hal ini sultan bersama ulama, terutama ulama yang menjadi anggota lembaga pemerintahan yang bernama Syara' Hukum merumuskan sebuah gagasan baru yang Islami yang diambil dari intisari nilai iman dan takwa guna memperkaya gagasan yang terkandung dalam adat Dana Mbojo. Gagasan baru itu diberi nama Maja Labo Dahu (malu dan takut). Maja Labo Dahu berisi perintah kepada seluruh lapisan masyarakat yang telah mengikrarkan kalimat tauhid untuk mengamalkan nilai-nilai keimanan dan ketakwaan sehari-hari baik dalam urusan =ubudiah maupun mu'amalah.

\footnotetext{
${ }^{2}$ Hilir Ismail, Maja Labo Dahu sebagai Falsafah Hidup dalam Konteks Masa Kini, Makalah dalam Seminar Nasional Sehari dan Pergelaran Kesenian, Bima 2001, 6.

${ }^{3}$ Wawancara dengan Putri Sultan Bima yang terakhir, Siti Maryam R. Salahuddin, Pada tanggal 25 Juni 2003 di kediamannya Museum Samparaja.
} 
Upaya memperkaya khazanah adat dengan memasukkan nilai-nilai yang Islami tidak akan bermakna apabila tidak diikuti dengan penyempurnaan norma. Karena itu, sultan sebagai penguasa bersama ulama menggunakan metode qiyas menyusun berbagai norma dan peraturan yang bersumber dari hukum Islam (alQur'an, alHadis, dan ljma') untuk dijadikan hukum adat. Itulah sebabnya, antara hukum Islam dengan hukum adat Mbojo sangat tipis perbedaannya karena dari segi substansinya, hukum adat Mbojo itu Islami. ${ }^{4}$

\section{Bidang Perkawinan dan Perceraian}

Transformasi dan perpaduan aturan hukum yang terjadi di Kesultanan Bima pada tahun $1640 \mathrm{M}$, tidak membawa dampak negatif ataupun keteganganketegangan antara hukum Adat Mbojo sebagai tuan rumah dan hukum Islam sebagai ajaran agama yang datang kemudian. Pada pelaksanaan hukum Islam, masyarakat Bima tidak memandangnya sebagai satu kutub yang bertentangan sama sekali dengan adat Mbojo, seperti yang telah disebutkan bahwa setelah Islam datang ke Bima dan dijadikan sebagai agama resmi kerajaan, secara otomatis adat yang tidak sesuai dengan ajaran Islam dihapus dan adat yang sesuai dengan Islam dipertahankan. Oleh karena itu dapat dikatakan bahwa adat Mbojo itu bersifat Islami. Wajah hukum di daerah Bima dibentuk oleh dua komponen, yaitu adat Mbojo dan hukum Islam. Dua komponen tersebut bukan merupakan dua sistem yang tidak dapat menerima kompromi, hukum Islam di satu pihak dan adat Mbojo di lain pihak merupakan satu kesatuan yang telah menjadi identitas masyarakat Bima, seperti yang dikatakan oleh Siti Maryam R. Salahuddin bahwa hukum Islam dan adat Mbojo itu saling melengkapi satu sama lainnya, ${ }^{5}$ sehingga terjadi suatu kerjasama yang baik antara keduanya dalam menjamin tegaknya hukum di Bima.

Sebagai identitas masyarakat di Bima, merupakan suatu kewajiban untuk menjaga keutuhan identitas tersebut dan untuk menyelesaikan masalah yang mungkin muncul dalam proses perpaduan antara hukum Islam dan adat Mbojo, maka Kecamatan atau ke-jeneli-an dibentuk suatu lembaga yang masing-masing mewakili keduanya. Setelah tahun 1908, pemerintahan Belanda melakukan intervensi yang sangat merugikan Kesultanan Bima, antara lain dengan menghapus sebuah lembaga yang bernama Mahkamah Syar'iyyah. Padahal lembaga ini merupakan suatu lembaga yang menjamin terlaksananya hukum Islam di Kesultanan Bima, tapi setelah terjadinya intervensi tersebut, secara otomatis pelaksanaan hukum Islam di Bima dapat dikatakan tidak berjalan lagi

${ }^{4}$ Ismail, Maja ..., 6.

${ }^{5}$ Wawancara dengan Putri Sultan Bima yang terakhir, Siti Maryam R. Salahuddin, pada tanggal 25 Juni 2003 di kediamannya Museum Samparaja. 
sebagaimana yang terjadi sebelum tahun 1908. Hal ini menyebabkan banyak kasus atau sengketa hukum yang tidak mendapat penyelesaian hukum sehingga terjadinya penumpukkan kasus atau sengketa hukum.

Setelah dibentuknya Badan Hukum Syara' dengan Surat Keputusan Sultan Bima No. 42 Tanggal 4 Mei 1947 yang diikuti dengan instruksi Sultan Bima tangal 4 Mei 1947, maka pelaksaan hukum Islam di Kesultanan Bima dapat berjalan dengan baik sesuai dengan aspirasi masyarakat Bima yang menginginkan agar hukum Islam dapat ditegakkan di Dana Mbojo. Pemberlakuan hukum Islam sebagai hukum positif di Kesultanan Bima setelah dibentuknya Badan Hukum Syara' dapat dilihat dari bentuk keputusan-keputusan yang dikeluarkan Badan Hukum Syara' dalam menyelesaikan kasus atau sengketa hukum yang terjadi di masyarakat dan yang dijadikan dasar hukum adalah hukum Islam. Berlakunya hukum Islam di Kesultanan Bima dapat dilihat dari berbagai bidang, yaitu bidang perkawinan, perceraian, kewarisan, dan perikatan. Sedangkan bidang pidana bukan merupakan wewenang dari Badan Hukum Syara', tapi merupakan wewenang dari pengadilan umum. ${ }^{6}$ Jadi, kewenangan absolut daripada Badan Hukum Syara' hanya pada kasus atau perkara perdata saja.

Aspek perkawinan dan perceraian dari hukum Islam berlaku dengan efektif di Kesultanan Bima. Pelanggaran terhadap ketentuan hukum Islam ini dihukum sesuai dengan ketentuan yang terdapat dalam hukum Islam. Hal ini terlihat pada penerapan prinsip Islam tentang pelanggaran taklik talak yang dilakukan oleh suami terhadap isteri, seperti kasus Im (nama singkatan) anak Jns sebagai isteri/penggugat dan Smdn H. Hsn sebagai suami/tergugat, bahwa Smdn telah melanggar taklik talaknya, yaitu telah 7 Bulan meninggalnya isterinya tanpa nafah lahir batin dan Im sebagai isteri mengajukan persoalan ini ke Badan Hukum Syara'. Berdasarkan pengajuan dari Im tersebut, maka Badan Hukum Syara' dengan Surat Keputusan tertanggal 2 Juli 1958 Nomor 16 tahun 1958, memutuskan dengan membenarkan tuntutan Im anak Jns dan memutuskan bahwa Smdn H. Hsn telah melanggar ikrar taklik talak, maka berlakukan hukum taklik talak Im anak Jns dinyatakan tertalak 1 (satu) dari suaminya Smdn H. Hsn. Surat Keputusan ini disetujui oleh Imam Swapraja Bima, Ketua Rapat beserta anggota dan penasehat yang kemudian ditetapkan dan dikuatkan oleh

${ }^{6}$ Wawancara dengan K.H. Zahruddin, mantan hakim/penghulu Badan Hukum Syara', pada tanggal 30 Juni 2003 dikediamannya di Desa Rontu dan wawancara langsung dengan K.H. M. Said Amin, Ketua MUI Kabupaten Bima, anggota Yayasan Islam dan Imam Majelis Adat Mbojo, pada tanggal 13 Agustus 2003. 
Dewan Pemerintahan Daerah Peralihan Bima pada tanggal 28 Oktober 1958. ${ }^{7}$ Gugatan isteri ini tergolong gugatan cerai taklik talak. Dari isi gugatan tersebut ternyata dapat diketahui bahwa pasangan ini sudah tidak lagi hidup dalam satu rumah tangga. Dalam petitumnya, isteri menuntut ke Badan Hukum Syara‘ agar menyatukan demi hukum jatuhnya talak. Terhadap gugatan isteri tersebut, suami tidak memberikan jawaban/tanggapan ataupun tuntutan balik yang berkaitan dengan kehidupan rumah tangganya. Berdasarkan gugatan tersebut, maka Badan Hukum Syara' memberikan keputusan bahwa pernikahan pasangan tersebut putus dengan talak satu karena pelanggaran janji pada taklik talak.

Berdasarkan putusan Badan Hukum Syara', bahwa perkara ini mencakup persoalan kehidupan rumah tangga yang pokok persoalannya terletak pada situasi di mana suami dan isteri tidak lagi terdapat keserasian sehingga rawan terjadinya perpecahan.

Bila kita memperhatikan secara cermat bahwa perkara ini termasuk dalam kategori yang tidak terlalu rumit. Penyelesaian pada perkara ini tidak melibatkan suami dalam persidangan sehingga tidak ada keberatan dari pihak suami terhadap gugatan yang dilakukan oleh sang isteri. Seperti diketahui perkara ini berpusat pada masalah cerai di atas pelanggaran taklik talak.

Terhadap putusan Badan Hukum Syara' pada diktum yang menjadi gugatan isteri yaitu perceraian dengan alasan pelanggaran taklik talak berdasarkan pada kesaksian isteri bahwa suaminya telah meninggalkannya selama 7 bulan sesuai dengan isi taklik talaknya. Kalaupun dalam hal nafkah selama suami meninggalkan rumah yang juga merupakan pelanggaran taklik talak yang juga tidak terdapat sanggahan dari suaminya dan nampaknya pengadilan merasa tidak perlu memeriksanya secara mendalam. Hal ini sama sekali tidak mengurangi sahnya secara hukum tentang pelanggaran taklik talak oleh suami. Ditambah lagi selama itu berarti suami tidak mempedulikan isteri dan ini juga merupakan pelanggaran taklik talak. Berdasarkan atas pertimbangan di atas Badan Hukum Syara' memberikan keputusan bahwa putusnya perkawinan pasangan tersebut karena pelanggaran terhadap taklik talak.

Kalau kita merujuk kepada Kompilasi Hukum Islam pada Bab VII tentang perjanjian perkawinan pada Pasal 45 dikatakan bahwa: - Kedua calon mempelai dapat mengadakan perjanjian perkawinan dalam bentuk: (1) taklik alak, (2) perjanjian lain yang tidak bertentangan dengan hukum Islam\|. Kemudian pada Pasal 46 (2), dikatakan bahwa: - Apabila keadaan yang disyaratkan dalam taklik

${ }^{7}$ Arsip Badan Hukum Syara' tentang taklik talak No. 16 Tahun 1958. Surat keputusan ini disetujui dan ditandatangani oleh Imam Swapraja Bima dan ditanda tangani oleh Majelis Hakim 
talak betul-betul terjadi kemudian, tidak dengan sendirinya talak jatuh. Supaya talak sungguh-sungguh

beserta anggota dan penasehat yang ditetapkan dan dikuatkan oleh Dewan Pemerintah Daerah Peralihan Bima.

jatuh, isteri harus mengajukan persoalanya kepengadilan agamall. ${ }^{8}$ Atas tindakan yang dilakukan oleh Smdn tersebut dianggap oleh Badan Hukum Syara' bertentangan dengan hukum Islam.

Adapun yang menjadi sumber pengambilan hukum dari permaslahan di atas adalah dengan merujuk langsung pada kitab-kitab fiqh, seperti Kitab Bughyah alMustarsydin. Dalam kitab ini diterangkan dengan jelas berbagai macam permasalahan yang dihadapi oleh umat Islam disertai pula dengan penyelesaiannya sesuai dengan syari'at Islam. Dasar itu, majelis hakim dalam Badan Hukum Syara' merasa tidak perlu lagi melakukan sebuah ijtihad hukum dalam mengambil keputusan dalam berbagai macam perkara yang dihadapkan kepadanya, termasuk perkara di atas. ${ }^{9}$

Hukum Islam yang berkembang di Kesultanan Bima bercorak Mazhab Sha $>f^{\prime}{ }^{\prime} i>$. Artinya, bila terjadi sengketa dalam masyarakat yang memerlukan penyelesaian menurut hukum Islam, perkara tersebut diselesaikan menurut pendapat yang terdapat dalam Mazhab Sha>fi'i>. Hal itu tercermin dalam kitabkitab fiqh yang dijadikan rujukan oleh Badan Hukum Syara'.

Kemudian kasus yang lain tentang seorang suami yang lalai dalam tugasnya sebagai kepala rumah tangga dengan tidak memberikan nafkah atau belanja kepada isterinya dan meninggalkan isterinya selama dua tahun tanpa nafkah, sehingga si isteri meminta agar perkawinannya difasakh oleh pengadilan. Dalam hal ini, Badan Hukum Syara' dalam keputusannya tentang surat fasakh nomor 27 tahun 1956 memutuskan fasakh antara Ftmh sebagai isteri dari kampung Sarae Kejenelian/Distrik Rasana'e Daerah Swapraja Bima, isteri dari saudara M. Tyb. Dikarenakan suaminya telah dua tahun pergi ke Sulawesi dengan tidak menyimpan dan mengirim nafkah/belanja untuk isterinya.

Pada Hari Senin tanggal 29 Oktober 1956 oleh Pengadilan Agama pada kantor Badan Hukum Syara' Daerah Swapraja Bima, telah memfasakhkan nikahnya suami isteri tersebut di atas dan difasakhkan dalam kedaan suci. ${ }^{10}$

${ }^{8}$ Abdurrahman, Kompilasi Hukum Islam, (Jakarta: Akademika Pressindo, 1995), 123.

${ }^{9}$ Wawancara dengan K.H. Zahruddin, mantan hakim/penghulu Badan Hukum Syara', pada tanggal 2 November 2003 di kediamannya di Desa Rontu.

${ }^{10}$ Arsip Badan Hukum Syara' tentang Surat Fasakh No. 27 Tahun 1956. Surat keputusan ini disetujui dan ditandatangani oleh pihak yang mengajukan fasakh dalam hal ini adalah saudara Fatimah dan ditandantangani oleh Majelis Hakim beserta anggota dan penasehat Badan Hukum Syara'. 
Tindakan yang dilakukan saudara $\mathrm{M}$. Tyb yang meninggalkan isterinya selama dua tahun tanpa memberikan nafkah terhadap isterinya tersebut dipandang oleh Badan Hukum Syara' bertentangan dengan hukum Islam. Dalam kasus ini juga Majelis Hakim dalam Badan Hukum Syara' merujuk kepada kitab-kitab fiqh Mazhab Sha>fi'i> sebagai sumber pengambilan hukumnya.

Kasus tersebut berawal dari sebuah perkawinan yang sah berdasarkan agama Islam. Setelah akad nikah, mereka bergaul layaknya suami-isteri, tapi dalam perkawinan tersebut tidak dikaruniai seorang anak pun. Suaminya meninggalkan seorang isteri selama dua tahun tanpa nafkah, baik nafkah lahir maupun bathin. Karena itu, penggugat menderita atas tindakan tergugat dan tidak mungkin lagi bersabar atas tindakan suaminya tersebut. Atas alasan tersebut penggugat mengajukan kepada Badan Hukum syara' agar perkawinan tersebut diputus dengan fasakh karena suaminya telah melanggar ikrar taklik talak yang pernah ia ucapkan sewaktu pernikahannya. Atas gugatan dari isterinya tersebut, tidak ada tanggapan ataupun keberatan dari suaminya. Hal ini kemungkinan terjadi karena tidak adanya komunikasi yang intensif antara suamiisteri tersebut ataupun tidak adanya usaha dari pihak pengadilan untuk menghadirkan tergugat untuk memberikan tanggapan ataupun keberatan terhadap gugatan isterinya tersebut.

Dalam keputusannya terhadap perkara tersebut, Badan Hukum Syara' memilih bentuk fasakh, yaitu sesuai dengan petitum penggugat. Hal ini dilakukan berdasarkan pertimbangan, yaitu: pelanggaran terhadap taklik talak yang dilakukan oleh sang suami terhadap sang isteri dan ditambah tidak memberikan nafkah lahir dan nafkah batin sehingga sang isteri merasa menderita dan tidak kuat lagi atas perlakuan suaminya tersebut.

Dalam Kompilasi Hukum Islam Bab XII tentang Hak dan Kewajiban Suamiisteri pada bagian satu (umum) dalam Pasal 77 (5) dikatakan bahwa: - Jika suami atau isteri melalaikan kewajibannya, masing-masing dapat mengajukan gugatan kepada Pengadilan Agama\|l. ${ }^{11}$ Kemudian pada Bab XVI tentang putusnya perkawinan pada bagian pertama (umum) dalam Pasal 116 (b) dikatakan bahwa: -Salah satu pihak meninggalkan pihak lain selama dua tahun berturut-turut tanpa izin pihak lain dan tanpa alasan yang sah atau karena hal lain diluar kemampuannya\|. ${ }^{12}$

Dari uraian di atas, tindakan Ftmh sebagai isteri memang benar mengajukan gugatan kepada Badan Hukum Syara' atas suaminya yang teah melalaikan tugas dan kewajiban sebagai suami dan atas dasar ini Badan Hukum Syara' memutuskan fasakh terhadap suami-isteri tersebut.

\footnotetext{
${ }^{11}$ Abdurrahman, Kompilasi ..., 132.

${ }^{12}$ Ibid, 141.
} 
Namun demikian, satu hal yang patut dipertanyakan atas keputusan Badan Hukum Syara' terhadap kedua kasus di atas, yaitu apa yang melatarbelakangi perbedaan keputusan Badan Hukum Syara' terhadap kedua kasus di atas yang pada dasarnya mempunyai kesamaan dalam materi perkara? Kalau kita perhatikan kedua kasus di atas, masing-masing mempunyai kesamaan dalam hal isi gugatan (petitum), yaitu pelanggaran terhadap taklik talak.

Pada kasus yang pertama, Badan Hukm Syara' memberikan keputusan hukumnya, yaitu jatuhnya talak satu terhadap isteri sebagai penggugat karena pelanggaran terhadap taklik talak yang dilakukan oleh suaminya. Tapi, pada kasus kedua, Badan Hukum Syara' memberikan keputusan hukumnya. yaitu memfasakh perkawinan antara penggugat dan tergugat karena pelanggaran terhadap taklik talak juga. Jadi, pada kedua kasus di atas, terjadi dua keputusan yang berbeda terhadap dua kasus yang sama dan diputus oleh Rapat Hukum Syara' yang sama pula atau diputuskan oleh majelis hakim yang sama.

Kalau kita memperhatikan petitum pada kasus yang pertama, yaitu penggugat menggugat agar hakim memberikan keputusan terhadap perkara yang diajukannya tanpa menyebutkan jenis vonis yang dia inginkan (hanya pengajuan untuk talak). Tapi pada kasus yang kedua, dalam petitumnya penggugat menggugat agar hakim memberikan keputusan fasakh terhadap perkawinannya, jadi di sini terlihat adanya perbedaan dalam bentuk vonis yang diinginkan oleh para penggugat. Oleh karena itu, Majelis hakim berbeda dalam keputusannya walaupun dalam jenis kasus yang sama. Di sinilah letak kejelian atau kecerdasan seorang hakim dalam memutuskan perkara seperti perkara di atas. Hal ini tidak terlepas juga dari upaya ijtihad yang dilakukan oleh hakim dalam mengeluarkan keputusan hukumnya, seperti dua kasus di atas yang pada dasarnya sama dalam materi perkaranya, tapi berbeda dalam keputusan hukumnya.

Penulis mendapatkan informasi bahwa yang menjadi sebab perbedaan keputusan pada dua kasus di atas terjadi karena perbedaan dalam isi gugatan yang diajukan oleh para penggugat. Pada kasus yang pertama, penggugat tidak menyebutkan keputusan atau vonis yang diharapkannya. Oleh karena itu, Majelis Hakim memberikan keputusan bahwa penggugat (isteri) tertalak satu, dengan pertimbangan sang suami diharapkan dapat dilihat pada surat pemeriksaan yang dilakukan oleh pihak Lebena"e yang berwenang terhadap penggugat. Sehingga, dalam keputusannya Majelis Hakim memutuskan fasakh atas suami isteri tersebut dikarenakan atas laporan isteri bahwa dia merasa menderita atas 
perlakuan suaminya dan tidak sanggup lagi diperlakukan bukan sebagai seorang isteri. $^{12}$

Dalam memberikan keputusan hukum, seorang hakim atau majelis hakim harus terbebas dari tekanan pihak-pihak tertentu yang menginginkan perkaranya dimenangkan dan juga hakim harus dalam keadaan sehat badan (tidak dalam keadaan sakit), sehat pikiran, tidak dalam keadaan emosi, marah maupun dalam kedaan yang menyebabkan terganggunya hakim dalam memberikan keputusan hukumnya, sehingga hakim dalam keputusannya tidak merugikan pihak-pihak yang berperkara.

Terlepas dari hal tersebut, putusan-putusan tersebut sangat adil dan bijaksana, karena isteri dalam kasus ini telah diselamatkan dari perbuatan zalim suaminya dan bagaimanapun bervariasinya keputusan hakim dalam kasus yang sama tersebut, yang jelas, keputusan hakim tidak dapat diganggu gugat dan keputusan tersebutlah yang terbaik.

Dari kedua contoh kasus atau perkara di atas dapat diambil sebuah sebuah kesimpulan bahwa Badan Hukum Syara' dalam melakanakan tugasnya benarbenar menggunakan hukum Islam yang merujuk pada kitab-kitab fiqh dalam pengambilan keputusannya dan pelaksanaan hukum Islam dalam bidang perkawinan dan perceraian berlaku efektif.

\section{Bidang Kewarisan}

Dalam masalah kewarisan, hukum Islam merupakan hukum positif dan pedoman pokok di Kesultanan Bima. Perkara-perkara yang diselesaikan oleh hakim dalam Badan Hukum Syara' dalam wilayah Kesultanan Bima diputuskan dengan berpedoman kepada hukum waris Islam atau fara'id. ${ }^{13}$

Sistem pemeriksaan persidangan Badan Hukum Syara' terhadap perkara perkawinan dan perceraian berbeda dengan pemeriksaan perkara kewarisan. Mengenai perkara perkawinan dan perceraian, usaha damai dari Majelis Rapat Hukum Syara' yang diajukan pada pemeriksaan perkara perkawinan atau perceraian tidak ada lagi. Tampaknya pemeriksaan pada tahap Badan Hukum Syara, lebih ditekankan pada penentuan dan penetapan hukumnya, atau mungkin juga kasus yang diajukan kepada Badan Hukum Syara' telah mencapai tingkat yang tidak mungkin dirukunkan kembali. ${ }^{14}$

\footnotetext{
12 Wawancara dengan K.H. Zahruddin, mantan hakim/penghulu Badan Hukum Syara', pada tanggal 2 Nopember 2003 di kediamannya di Desa Rontu

${ }^{13}$ Wawancara dengan K.H. Zahruddin, mantan hakim/penghulu Badan Hukum Syara', pada tanggal 30 Juni 2003 di kediamannya di Desa Rontu

${ }^{14}$ Pada kasus taklik talak, tekanan pemeriksaannya terletak pada pembuktian perbuatan hukum yang diadukan oleh pihak isteri telah dilakukan oleh suami atau belum, sebagai syarat untuk menyatakan jatuhnya talak.
} 
Mengenai perkara kewarisan, dari berkas perkara di Badan Hukum Syara‘ dijumpai adanya pemeriksaan gabungan, yakni sengketa hak, hibah, wasiat, dan kewarisan. Lahirnya sengketa hak kelihatannya bermula dari akibat adanya perbuatan hukum atau wasiat yang terjadi pada masa-masa sebelumnya atau karena perbedaan pemahaman mengenai deretan atau urutan kedudukan di antara penerima wasiat.

Dalam penyelesaian perkara tersebut, Badan Hukum Syara' baik diminta atau tidak diminta oleh pihak pendakwa. Pemeriksa unsur hibah atau wasiat terlebih dahulu sebelum memeriksa perkara kewarisannya. Hal itu dilakukan untuk mengetahui sebab-sebab penguasaan harta warisan.

Dalam kasus tersebut, Badan Hukum Syara' mula-mula memeriksa status harta warisan dalam kaitannya dengan hibah dan wasiat, kemudian memeriksanya untuk difaraidkan. Pemeriksaan perkara kewarisan akan melahirkan sebuah perdamaian antara pihak pendakwa, terdakwa maupun pihak lain yang berkepentingan. Dalam perdamaian itu, dicantumkan dalam status harta dan jumlah hak masing-masing pihak atau dengan perkataan lain perdamaian itu adalah pernyataan unutk melepaskan semua hak sebelumnya yang melekat pada harta dan selanjutnya pernyataan bahwa harta tadi telah dapat difaraidkan.

Hal tersebut di atas sesuai dengan kasus yang terjadi antara Djfr bin Hsn sebagai penuntut dan Is anak sebagai tertuntut. Dalam kasus ini, Djfr menuntut agar sawah peninggalan dari saudaranya yang bernama En dibagikan kepada ahli waris yang berhak mendapatkannya, dalam hal ini En mempunyai beberapa orang saudara, yaitu Djfr, Dr, Tk, dan Hr. Sebelum meninggal dunia, En telah menghibahkan beberapa petak sawahnya kepada anaknya Isa atau cucunya En yang bernama Mhmd Thr dan Abdrhmn. Akan tetapi Djfr menuntut agar sawah tersebut dibagikan kepada ahli warisnya dan Djfr mengajukan permasalahan ini ke badan hukum syara'. Setelah membaca surat pemeriksaan dari Lebena"e yang berwenang, maka Badan Hukum Syara' memutuskan untuk menolak tuntutan yang dilakukan oleh Djfr terhadap Is anak N. Badan Hukum Syara' menganggap bahwa sawah yang dituntut oleh Djfr tersebut statusnya bukan lagi harta peninggalan, tetapi sawah tersebut telah dihibahkan kepada cucunya dan telah menjadi hak milik yang sah dari cucunya tersebut.

Dalam hal ini, Badan Hukum Syara' mengeluarkan Surat Keputusan tertanggal 16 Oktober 1958, Vonis No. 28/58 yang ditetapkan dan dikuatkan oleh Pemerintah Daerah Swatantra Tingkat II Bima tanggal 26 Maret 1959 No. 3/59. ${ }^{15}$ Setelah Badan Hukum Syara' memberikan keputusan sengketa hak dari harta

${ }^{15}$ Arsip Badan Hukum Syara‘ tanggal 16 Oktober 1958. 
warisan tersebut, maka harta warisan En dapat dibagikan kepada ahli waris yang berhak mendapatkannya dan pembagian warisan tersebut dibagi berdasarkan hukum kewarisan Islam atau Fara'id.

En meninggalkan harta berupa: a. Pusaka, sebanyak 1700. -, 2. Warisan dari Kb, Rp. 285. 71 5/7. Kemudian dijumlahkan menjadi Rp. 1985. 71 5/7. Harta peninggalan tersebut dibagikan kepadals sebagai anak perempuannya dari sisanya untuk Ashabah (Djfr, Tk, dan Dr sebagai saudara En). Lebih rincinya pembagian harta peninggalan En kepada ahli warisnya sebagai berikut:

1. Is $=1 / 2 \times \operatorname{Rp} 1985.715 / 7=\operatorname{Rp} .992 .855 / 7$

2. Ashabah = Rp $992.855 / 7$
a. $\operatorname{Djfr}(\mathrm{sdr}$ lk) = 2/4x Rp. 992. 85 5/7 = Rp. $496.406 / 7$
b. $T$ k (sdr pr) = 1/4 X Rp. $992.855 / 7=$ Rp. $248.213 / 7$
C. $\operatorname{Dr}(\mathrm{sdr} p r)=1 / 4 \times \operatorname{Rp} .992 .855 / 7=$ Rp. $248.213 / 7 .{ }^{16}$

Kemudian masing-masing ahli waris mendapatkan warisan sebagai berikut:

1. Bagian Is Rp. 992. 85 5/7 dan mendapat satu petak tanah sawah seharga Rp.

1000.-, kemudian sisanya yaitu Rp. 7.14 2/7.

2. Bagian Djfr: dari kb. Rp. 285. 71 3/7 dan dari En Rp. 496.42 6/7, jadi berjumlah 782. 14 2/7. Dan mendapat satu petak sawah So Lelu seharga Rp.

1000.-, jadi kelebihannya Rp. 217. 85 5/7.

3. Bagian Hr: dari kb. Rp. 142. 85 5/7 dan dari En Rp. 248. 21 3/7, jadi berjumlah 391.07 1/7.

4. Bagian Tk: dari kb. Rp. 142. 85 5/7 dan dari En Rp. 248. 21 3/7, jadi berjumlah Rp. 391.07 1/7.

5. Bagian Dr: dari kb. Rp. 142. 85 5/7.

Kemudian dibagikan harta waris En dari peninggalan saudara kandungnya (Kb) pada ahli warisnya yaitu penuntut dan tertuntut dan mendapatkan bagian masing-masing yaitu: Satu petak sawah So Tampaseharga Rp. 700. -, kekurangannya Rp. 225, karena mereka terima dari kelebihan: (1) Is Rp. 7.14 2/7, (2) Djfr Rp. 217. 85 5/7, jadi jumlahnya Rp. 225. -,

Perkara kewarisan tersebut di atas menarik untuk dicermati karena dalam satu kasus terdapat dua sengketa yang berbeda tapi saling berkaitan satu sama

\footnotetext{
${ }^{16}$ Penjelasan lebih detailnya lihat di Arsip Badan Hukum Syara', tanggal 16 Oktober 1958.
} 
lainnya. Sengketa yang pertama adalah sengketa hak atas sawah peninggalan dari En sebagai pewaris dan yang kedua adalah masalah pembagian waris dari sawah sengketa hak tersebut. Yang menarik adalah bahwa sawah tersebut telah dihibahkan oleh En kepada kedua orang cucunya sebelum dia meninggal dunia. Sedangkan Djfr sebagai penuntut, menuntut agar sawah peninggalan dari En tersebut dibagaikan kepada ahli warisnya, yaitu empat orang saudaranya yang tersebut di atas termasuk Djfr sendiri.

Dalam hukum Islam, harta yang telah dihibahkan tidak dapat dijadikan harta peninggalan atau harta warisan yang harus dibagikan kepada ahli warisnya yang berhak, tapi telah menjadi hak yang sah orang yang telah menerima hibah tersebut. Lain halnya jika pemberian hibah tersebut diberikan kepada anak kandung, hal ini dapat dijadikan sebagai harta warisan.

Pemberian hibah dari En kepada cucunya tersebut dibenarkan oleh beberapa orang saksi yang secara langsung mengetahui duduk perkara dari masalah hibah tersebut, kesaksian para saksi tersebut dilakukan secara tertulis dan menjadi bahan pertimbangan bagi Rapat Hukum Syara' dalam memutuskan perkara tersebut.

Hal inilah yang menjadi pertimbagan Rapat Hukum Syara' dalam memutuskan untuk menolak tuntutan dari penuntut yaitu Djfr dan membenarkan keterangan tertuntut dari penuntut yaitu Is bahwa sawah tersebut telah dihibahkan kepada cucunya En dan memutuskan bahwa sawah tersebut tidak dapat dibagikan kepada ahli waris dari En.

Dalam pertimbangan hukum Badan Hukum Syara' telah melihat dengan jeli atas pokok perkara ini, yang menurutnya dapat dibagi menjadi dua pokok, pertama, bahwa harta atau sawah yang dituntut oleh penuntut tersebut telah dihibahkan oleh pewaris, kedua, harta yang telah dihibahkan tidak dapat diwariskan atau tidak dapat dijadikan harta warisan.

Hal ini mengingatkan kita betapa perlunya Hakim itu bersifat cermat dan tanggap menangani perkara. Dalam pesan Khalifah Umar bin Khattab, beliau mengatakan antara lain: - Maka pahamilah akan perkara yang diajukan kepada anda dan kemudian pahami sekali lagi apabila diajukan kepadamu suatu perkara yang tidak terdapat nashnya di dalam al-Qur'an maupun dalam Sunnah, kemudian bandingkanlah perkara-perkara itu dan perhatikanlah (perkara) yang serupa (hukumnya dengan perkara-perkara itu), kemudian pegangilah mana (hukum) yang menurut pendapatmu lebih di ridhai Allah dan lebih mendekati kebenaran $\| .{ }^{17}$

${ }^{17}$ Untuk lebih lengkapnya, baca Ibnul Qayyim al-Jauziyyah, A“/amul ..., jilid I, 85-86. 
Namun demikian, Rapat Hukum Syara' dalam Badan Hukum Syara' dalam pertimbangan hukumnya setelah membaca surat pemeriksaan dari Lebena" $e$, mendengar keterangan penuntut dan tertuntut serta mendengar keterangan saksisaksi tertuntut dan berpendapat bahwa harta yang merupakan obyek warisan yang berupa sawah tersebut, mengandung sengketa hak, apakah sawah tersebut benarbenar milik pewaris atau bukan, baik keseluruhan atau sebagian. Karena itu Rapat Hukum Syara' berpendapat dan memutuskan seperti yang tersebut di atas.

Setelah Badan Hukum Syara' memutuskan harta mana saja yang menjadi harta warisan dan harta yang bukan harta warisan, kemudian membagikan harta warisan tersebut kepada ahli warisnya sesuai dengan hukum kewarisan Islam atau fara'id, seperti yang telah diuraikan di atas yang disertai pula dengan pembagian bahagian masing-masing ahli warisnya.

Sekali lagi, dalam hal menentukan harta warisan dan bukan harta warisan dalam kasus kewarisan, Badan Hukum Syara' baik diminta ataupun tidak diminta oleh para ahli waris terlebih dahulu memeriksa unsur-unsur yang lain dalam harta warisan tersebut sehingga tampak jelas harta warisan yang harus difara'idkan. Sehingga dalam pemeriksaan perkara kewarisan akan melahirkan sebuah perdamaian antara para ahli waris dan dalam perdamain tersebut kan dicantumkan oleh Badan Hukum Syara' status dan jumlah hak masing-masing ahli waris.

Apa yang terjadi dalam Badan Hukum Syara' Kesultanan Bima dalam penerapan hukum waris, begitu juga dalam hukum perkawinan dan perceraian sebagaimana yang telah dikemukakan di atas, bukanlah pelaksanaan hukum Adat Mbojo sebelum Islam, tetapi yang terjadi adalah pelaksanaan hukum Islam secara menyeluruh dalam hal-hal yang tersebut di atas.

\section{Bidang Perikatan}

Dalam hubungan keperdataan yang menyangkut perikatan, hak-hak dan kewajiban-kewajiban yang berlaku terhadap orang-orang atau pihak-pihak tertentu yang berhubungan dengan harta yang dalam hukum Islam dapat disebut dengan aspek Mu'amalah. Kesultanan Bima terlihat menggunakan prinsip-prinsip yang berlaku dalam hukum Islam dalam menyelesaikan sengketa-sengketa yang berkaitan dengan masalah perikatan. ${ }^{18}$

Walaupun penulis tidak menemukan berkas-berkas perkara yang menyangkut masalah perikatan secara spesifik, namun dalam hal ini penulis

${ }^{18}$ Wawancara dengan K.H. Zahruddin, mantan hakim/penghulu Badan Hukum Syara', pada tanggal 30 Juni 2003 di Desa Rontu. 
mendapatkan informasi yang sangat akurat tentang berlakunya hukum Islam dalam menangani masalah perikatan yang terjadi dalam masyarakat Bima di wilayah Kesultanan Bima.

Seperti yang telah penulis sebutkan pada bab sebelumnya bahwa adanya berkas-berkas perkara yang hilang ataupun karena sebab-sebab yang lain yang mungkin diluar jangkauan manusia untuk mengetahuinya, sehingga benda yang bersejarah itu hilang entah kemana ataupun karena ketidaktahuan arti dari pentingnya nilai-nilai sejarah dari benda-benda atau arsip-arsip tersebut sehingga penulis tidak mandapatkan satu berkas pun yang berkaitan dengan masalah perikatan atau mu'amalah tersebut.

Terlepas dari masalah tersebut di atas, berdasarkan hasil wawancara yang penulis lakukan dengan beberapa orang tokoh yang sangat berkompeten dalam masalah ini, yang hasilnya bahwa Badan Hukum Syara' dalam menyelesaikan sengketa yang berkaitan dengan masalah perikatan atau mu'amalah menggunakan prinsip-prinsip yang berlaku dalam hukum Islam.

Sebagaimana yang penulis sebutkan di atas bahwa penulis tidak menemukan berkas-berkas perkara yang secara spesifik dari Badan Hukum Syara' yang memberikan sebuah keputusan hukum terhadap masalah yang berkaitan dengan perikatan. Namun jika perhatikan pada kasus yang penulis sebutkan di atas tentang kewarisan, yaitu perkara antara Djfr sebagai penuntut dan Is anak En sebagai tertuntut, terlihat adanya sebuah sengketa yang berkaitan dengan masalah perikatan. Dalam hal ini, Djfr menuntut agar sawah milik En dibagikan kepada ahli waris yang berhak mendapatkannya, dalam kenyataannya bahwa sawah tersebut telah dihibahkan kepada cucunya En atau anaknya Is yang bernama Mhmm Thr dan Abdrhmn sebelum En meninggal dunia

Berdasarkan surat pengakuan dari beberapa orang saksi yang membenarkan bahwa sawah tersebut telah dihibahkan kepada cucunya, maka Badan Hukum Syara' menolak tuntutan yang dilakukan oleh Djfr dan menetapkan bahwa sawah yang telah dihibahkan tersebut bukan harta peninggalan dari En yang harus dibagikan kepada ahli warisnya. ${ }^{19}$ Sawah atau harta tersebut telah menjadi hak yang sah dari cucunya En yaitu Mhmmd Thr dan Abdrhmn dan sawah tersebut bukan sebagai harta warisan.

Badan Hukum Syara' dalam keputusannya di atas didasarkan kepada Hukum Islam, bahwa harta yang telah dihibahkan bukan merupakan harta peninggalan yang harus dibagikan kepada ahli waris yang berhak mendapatkannya. Hal ini terkecuali apabila hibah tersebut diberikan kepada anak kandung yang pada akhirnya akan dapat diperhitungkan sebagai warisan dan hibah yang telah

\footnotetext{
${ }^{19}$ Arsip Badan Hukum Syara', tanggal 16 Oktober 1958.
} 
diberikan tidak dapat ditarik kembali, kecuali hibah orang tua kepada anaknya. ${ }^{20}$ Tapi, dalam kasus di atas hibah tersebut bukan diberikan kepada anaknya, tetapi diberika kepada cucunya, yang secara hukum tidak dapat ditarik kembali ataupun diperhitungkan sebagai warisan.

Hal inilah yang menjadi pertimbangan bagi Badan Hukum Syara' dalam memutuskan perkara tersebut di atas, yang dalama keputusanya menolak tuntutan dari penuntut yang menginginkan agar harta yang jelas-jelas telah dihibahkan tersebut dibagikan kepada pihak ahli waris yang membenrakan keterangan tertuntut serta memutuskan bahwa sawah tersebut sebagai harta hibah yang tidak dapat dibagikan pada ahli waris dari almarhum En.

Dari kasus-kasus yang telah dikemukakan, terlihat bahwa hukum Islam merupakan sumber hukum dan hukum positif di Kesultanan Bima. Oleh sebab itu, bila dihubungkan dengan dasar pemikiran dari teori Receptie yang di dukung oleh Snouck Hurgronje, maka kesimpulan teori ini tidak memperoleh bukti-bukti pendukung dalam lingkungan hukum daerah Kesultanan Bima. Teori Receptie, yang mendapat pengakuan secara hukum melalui Pasal 134 ayat (2) dari IS (IndischeStaatregeling) 1929, mengandung pengertian bahwa hukum Islam diberlakukan di kalangan umat Islam bila hukum Islam itu telah menjadi hukum Adat. ${ }^{21}$ Dengan demikian, Teori Receptie memandang hukum Islam bukan sebagai hukum positif. Bila hukum Islam telah menjadi hukum Adat barulah di menjadi hukum positif.

Bila dihubungkan kasus yang terjadi di Bima dengan apa yang terjadi di Minangkabau sebagaimana yang diungkapkan oleh maksud pepatah adat Minangkabau yang menggambarkan hubungan Islam dan Adat, Adat bersendi Syarak, Syarak bersendi kitabullah, Syarak Mangato, Adat mamakai, maka rumusan tersebut umumnya sesuai dengan hubungan Hukum dan Syara' yang terjadi di Kesultanan Bima. Di Kesultanan Bima, seperti yang tersebut pada pembahasan terdahulu, menggambarkan hubungan antara Hukum dan Syara', bahwa Hukum dan Syara' adalah merupakan Nawa Labo Sarumbu yang berarti bahwa nyawa dan tubuh secara bulat, dan juga dalam ungkapan yang berbunyi: Mori ro madena dou mbojo ake kai hukum Islam edeku, yang berarti bahwa hidup dan matinya orang Bima harus dengan hukum Islam, dan Bune santika Syara" ederu na kapahuku rona kandandina rawi, hukum ma katantu ro maturuna, yang

${ }^{20}$ Lihat Kompilasi Hukum Islam pada Bab VI tentang Hibah pada Pasal 211 dan 212.

${ }^{21}$ Terjemahan Indonesia dari pasal 134 ayat (2) baru IS tersebut adalah -Dalam hal terjadi perkara perdata antara sesama orang Islam akan diselesaikan oleh orang Hakim Agama Islam apabila hukum adat mereka menghedakinya dan sejauh tidak ditentukan lain dengan sesuatu ordonasill. Lihat, Talib, Receptio ..., 44. 
berarti bahwa syara' itu yang mewujudkan dalam kenyataan hidup sedangkan hukum yang menetapkan dan menunjukkan jalan. ${ }^{22}$

Perwujudan dari pepatah dan ungkapan tersebut terlihat pada penyerapan unsur-unsur hukum Islam oleh adat setempat sehingga yang disebut dengan adat tidak lain dari hukum Islam itu sendiri. Perkembangan adat di daerah itu selalu memperhatikan ketentuan Syara'. Ketentuan adat yang bertentangan dengan Syara' dihapus oleh pihak penguasa Kesultanan Bima dan diganti dengan adat yang lebih sesuai dengan Syara'.

Hal ini terjadi karena adanya dukungan langsung dari pihak penguasa dalam memantau pelaksanaan hukum Islam dan penguasa memberikan perintah langsung kepada rakyatnya agar seluruh lapisan masyarakat Bima dalam kehidupannya melaksanakan hukum Islam. Oleh sebab itu, penerimaan adat atas hukum Islam berjalan dengan mulus dan penerimaan hukum Islam oleh adat dengan cepat dan tidak menimbulkan konflik. ${ }^{23}$

Memperhatikan keadaan berlakunya hukum Islam di Kesultanan Bima dapat dikatakan bahwa hukum Islam merupakan inti dari hukum yang berlaku di Kesultanan Bima. Hukum Islam bukan hanya sebagai hukum materiil yang berlaku mandiri dengan tidak memerlukan legalisasi dari unsur lainnya, keberadaannya diterima dan diserap oleh adat Dana Mbojo.

\section{Catatan Akhir}

Setelah Indonesia merdeka tepatnya pada tahun 1947 atas inisiatif Sultan Bima mengeluarkan Surat Keputusan No. 42 tanggal 4 Mei 1947 tentang pembentukan Badan Hukum Syara' yang diikuti dengan aturan organik dalam Instruksi Sultan Bima tanggal 4 Mei 1947, maka secara otomatis pelaksanaan hukum Islam di Kesultanan Bima telah berlaku lagi setelah pemerintahan Belanda menghapus kekuasaan Mahkamah Syar'iyyah. Badan Hukum Syara' menitikberatkan aktivitasnya pada pelaksanaan hukum Islam dalam bidang perkawinan, perceraian, perwakafan, hibah, kewarisan, pendidikan dan kegiatan keagamaan lainnya. Pembetukan Badan Hukum Syara' merupakan wujud dari aspirasi masyarakat yamg menginginkan berlakunya hukum Islam di Kesultanan Bima secara menyeluruh, dan Badan Hukum Syara' adalah merupakan wajah Islam di Bima.

${ }^{22}$ Dari rumusan ungkapan dari kedua daerah ini, baik dalam bentuk gabungan antara keduanya maupun dalam bentuk terpisah, tidak memberi pengakuan terhadap teori Receptie, bahkan menolaknya.Sebab rumusannya tidak dimaksudkan untuk membatasi berlakunya hukum Islam, bahkan sebaliknya.

${ }^{23}$ Kasus yang terjadi di Bima, hampir sama atau bisa dikatakan sama dengan kasus yang terjadi Kesultanan Siak Sri Indrapura Melayu dalam hal yang menyangkut hubungan antara hukum Islam dan adat. 
Pelaksanaan hukum Islam dalam Badan Hukum Syara' berlaku efektif, hal ini terbukti dalam kasus-kasus, seperti kasus dalam pelanggaran taklik talak yang terjadi antara Im dan suaminya Smdn yang diputus talak satu oleh Badan Hukum Syara' dikarenakan Smdn sebagai suami telah melanggar ikrar taklik talak yaitu meninggalkan isteri selama 7 (tujuh) bulan tanpa nafkah lahir dan batin, kemudian dalam kasus fasakh yang terjadi antara Ftmh sebagai Isteri dan M. Tyb sebagai suami, di mana suami telah melanggar ikrar taklik talak yaitu meninggalkan isteri selama 2

(dua) tahun tanpa nafkah lahir dan batin dan isteri menggugat yang dalam petitumnya meminta agar majelis hakim mengabulkan permintaannya, demikian juga dalam kasus kewarisan dan perikatan (mu'amalah), terlihat hukum Islam merupakan dasar dan sumber hukum dari penyelesaian kasus-kasus tersebut dan kitab-kitab fiqh merupakan rujukan dan sumber pengambilan hukum bagi Badan Hukum Syara' dalam pengambilan keputusan hukumnya.

Jika teori Receptie dimaksudkan untuk menyatakan bahwa hukum Islam tidak berlaku dalam masyarakat, dalam arti bahwa masyarakat tidak mengakui hukum Islam sebagai hukum mereka dan yang mereka akui sebagai sumber hukum adalah adat mereka, maka teori ini tidak terbukti sama sekali dalam wilayah hukum Kesultanan Bima. Kasus-kasus yang dibawa ke Badan Hukum Syara', sebagaimana yang telah dikemukakan, membantah isi teori tersebut. Memperhatikan sejarah lahir dan maksud teori Receptie serta dihubungkan dengan data pendukung dari fakta-fakta yang dikemukakan dapat dikatakan bahwa teori tersebut bukanlah teori dalam arti yang sebenarnya, teori tersebut tidak lain dari kebijaksanaan kolonial Belanda belaka. Teori yang sebenarnya adalah jika teori tersebut didukung oleh data dan fakta empirik yang terjadi dalam masyarakat.

Bentuk perpaduan antara adat dengan Islam di Kesultanan Bima, yaitu kecenderungan mengambil alih ketentuan-ketentuan hukum Islam dan menyebutnya sebagai adat. Hal ini memperlihatkan bagaimana kuatnya pengaruh Islam terhadap adat. Mengingat kuatnya pengaruh Islam dalam adat Mbojo dapat dimengerti mengapa Dou Mbojo sangat kuat memegang adatnya yang tercermin dalam ungkapan, Nawa Labo Sarumbu yang berarti bahwa nyawa dan tubuh secara bulat, dan juga dalam ungkapan yang berbunyi: Mori ro madena dou Mbojo ake kai hukum Islam edeku, yang berarti bahwa - Hidup dan matinya orang Bima harus dengan hukum Islamll, dan Bune Santika Adat Ederu Na Kapahuku Rona Kandandina Rawi, Hukum Ma Katantu Ro Maturuna, yang berarti bahwa Syara' itu yang mewujudkan dalam kenyataan hidup sedangkan hukum yang menetapkan dan menunjukkan jalan\|. Adat bukan hanya sekedar ketentuan 
hidup yang sudah dibiasakan, tetapi menyangkut hubungan dengan agama Islam yang dijadikan sebagai dasar falsafah adat.

\section{DAFTAR PUSTAKA}

A. Hasjmy, Sejarah Kebuadayaan Islam, Jakarta: Bulan Bintang, 1995.

A. Syalabi, Sejarah Dan Kebudayaan Islam, Jakarta: al-Husna Zikra, 1997, Jilid III. Abdullah, A. Gani, Keanekaragaman Peradilan Agama dan Perkembangannya di Indonesia, Seri Monografi.

Agama dan perubahan sosial, Badan Penelitian dan Pengembangan Agama, Depag. RI, 1978.

-, Pengantar Kompilasi Hukum Islam dalam Tata Hukum Indonesia, Jakarta: GIP, 1994.

---------, Badan Hukum Syara" Kesultanan Bima 1947-1957: Sebuah Studi Mengenai Peradilan Agama.

Abdurrahman, Kompilasi Hukum Islam, Jakarta: Akademika Pressindo, 1995.

Abidin, Ibn, Nasyr al-"urf, Mesir: Mathba'ah Ma'arif Suriah al-Jalilah, $1301 \mathrm{H}$.

Ahmad, Abdullah, Kerajaan Bima dan Keberadaanya, Bima: Ketikan, 1992.

Ali, Muhammad Daud, Hukum Islam dan Pembangunan Hukum, Nasional: Suatu

Analisa TerhadapRUU Peradilan Agama" dalam Hukum dan Pembangunan, No. 6 Tahun ke XIX, Desember 1989.

----------, Hukum Islam,Jakarta: Rajawali Press, 1993.

Al- Mawardiy, Al-Ahkam al-Sulthaniyyah, Mesir: Musthafa al-Babiy al-Halabiy, 1973.

Al-Kahlaniy, Muhammad bin Ismail, Subul as-Salam, Beirut: Dar al-Fikr, t.t., Jilid IV.

Arifin, Busthanul, Pelembagaan Hukum Islam di Indonesia, Jakarta: Gema Insani Press, 1996.

Ash-Shiddiqiy, Hasybi, Peradilan dan Hukum Acara Islam, Bandung: al-Ma'arif, 1964.

------------, Hasybi, Falsafah Hukum Islam, Jakarta: Bulan Bitang, 1993.

Azra, Azyuardi, Jaringan Global dan Lokal Islam Nusantara, Jakarta: Mizan, 2002.

Bik, Khudariy, Tarikh al-Tasyri" al-Islamiy, Mesir: al-Maktabah al-Tijariyyah alKubra, 1965.

Bisri, Cik Hasan, Peradilan Islam dalam Tatanan MasyarakatMasyarakat Indonesia, Bandung: Rosdakarya, 1997.

Cary, Peter, Asal-Usul Perang Jawa, Sepoy dan Lukisan Raden Saleh, Jakarta:

Pustaka Azest, 1986.

Djamil, Fathurrahman, Filsafat Hukum Islam, Jakarta: LOGOS, 1999. 
Daud, Abu, Sunan Abi Daud, Mesir: Mustafaal-Babi al-Halabi, 1952.

Harjono, Anwar, Hukum Islam, Keluasan dan Keadilannya, Jakarta Bulan Bintang, 1968.

Hasan, Hasan Ibrahim, Tarikh al-Islam al-Siyasi, Beirut: Maktabah al-Nahdhah, t.t. Hasan, Ibrahim, Tarikh Islam al-Siyasi, TP, t.t., Jilid I.

Hosen, Ibrahim, Fiqh Perbandingan, Jakarta: Yayasan ihya' Ulumuddin, 1971.

------------, Perluasan cakrawala Zakat dan Efisiensi Pendayagunaannya, dalam Umar Luthfi, - Hukum dan Perubahan Struktur Kekuasaan\|, Pekanbaru: Susqa Press, 1991.

Ismail, Hilir, Peranan Kesultanan Bima dalam Perjalanan Sejarah Nusantara, Ketikan, Mbojo, Bima, 1988.

-, Islam, Jiwa dan Wajah Kita (Renungan Menyambut Hari Jadi 363

Bima), Bima Ekspres, edisi Selasa, 1 Juli 2003.

----------, Maja Labo Dahu Sebagai Falsafah Hidup dalam Konteks Masa Kini, Makalah dalam Seminar Nasional Sehari dan Pergelaran Kesenian, Bima 2001.

--, Sosialisasi Maja Labo Dahu, Makalah, Bima, 1997.

-, Pemahaman Kembali Sejarah Bima dan Daerah Lain di Pulau

Sumbawa: Suatu Tinjauan Sejarah Lokal), Makalah dalam Dialog

Kesejarahan, Lawatan Sejarah Sumbawa Bima Juni 2003, Direktorat

Sejarah Kebudayaan dan Pariwisata Jakarta 2003, Bima NTB.

Ka'bah, Rifyal, Hukum Islam di Indonesia, Jakarta: Yarsi, 1999.

Khallaf, Abdul Wahab, Ilmu Ushul Fiqh.

Latif, Djamil, Kedudukan dan Kekuasaan Peradilan Agama di Indonesia, Jakarta:

Bulan Bintang, 1983.

Lev, Daniel S., Peradilan Agama Islam di Indonesia, Jakarta: Intermasa, 1980.

-, Peradilan Agama Islam di Indonesia, Jakarta: Intermasa, 1980.

Loir, Henry Dhambert dan Salahuddin, Siti Maryam R., Bo Sangaji Kai (Catatan

Kerajaan Bima), Jakarta: Ecole Francaise d'Extreme-Orient dan Yayasan

Obor Indonesia, 1999.

Madkur, Salam, al-Qadha" fi al-Islam, Kairo: Dar al-Nahdhah al-Arabiyah, 1964.

, Peradilan Dalam Islam, terj. Imron AM, Surabaya: Bina IImu, 1982.

Mahmashani, Sonhi, Falsafah al-Tsyri" fi al-Islam, alih bahasa Ahmad Soejono, Bandung: al-Ma'arif, 1981.

Mu'in, Bahi Abdul, Tarikh al-Qadhi fi al-Islam, T.P, t.t..

Musa, Muhammad Yusuf, Tarikh al-Fiqh al-Islamiy, Kuwait: Maktabah al-Sundus, t.t.

Sabrien, Zufran, Peradilan Agama Dalam Wadah Negara Pancasila: Dialog

Tentang RUUPA, Jakarta: LOGOS, 2001. 
Subekti dan Tjitrosidibjo, Kamus Hukum, Jakarta: Pradnya Paramita, 1969.

Suny, Ismail, dalam Cik Hasan Basri, Hukum Islam dalam Tatanan Masyarakat Indonesia, dalam - Tradisi dan Inovasi Keislaman di Indonesia dalam Bidang Hukum Islam\|, Bukit Pamulang: LOGOS Wacana IImu, 1998 M.

Syarifuddin, Amir, Meretas Kebekuan ljtihad, Jakarta: Ciputat Press, 2002.

Thalib, Sajuti, Receptio A Contrario, Jakarta: Bina Aksara, 1985.

Zahra, Muhammad Abu, Ushul al-Fiqh, Dar al-Fikr al-Arabiy, Cairo, 1957. 